QIJIS: Qudus International Journal of Islamic Studies Volume 5, Issue 2, August 2017

\title{
القواعد الفقهية الخمسة الكبرى في باب العبادات من كتاب إعانة الطالبين للسيد البكري
}

\section{Lathifah Munawaroh}

UIN Walisongo Semarang, Indonesia

lathifah.munawaroh@walisongo.ac.id

\section{الملخص}

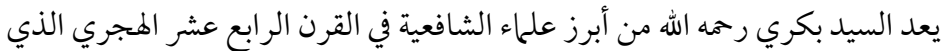

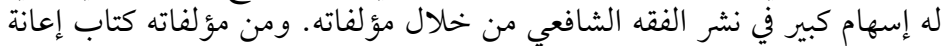

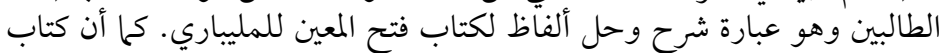

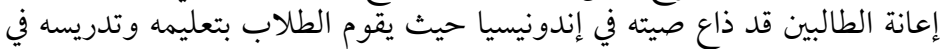

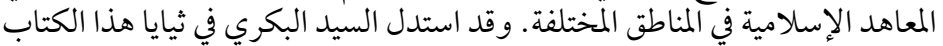

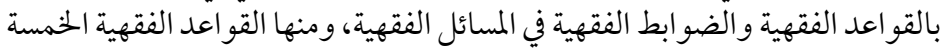

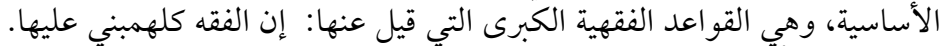

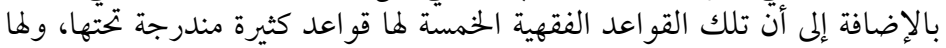

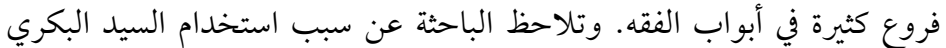

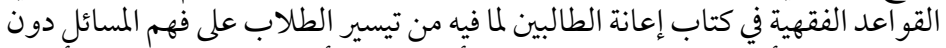

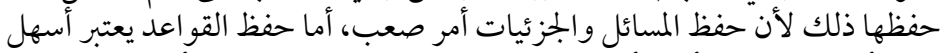

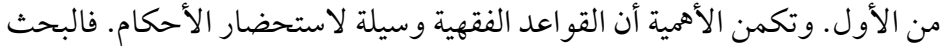

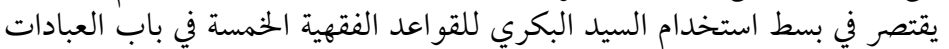
فقط دون" أبو اب أخرى أبنح.

الكلمات المفتاحية: القواعد الفقهية الخمسة الكبرى، السيد البكري، الفقه الشافعي. 


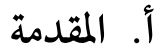

إن لدراسة القواعد الفقهية أهمية كثيرة. وقال الزركشي مؤكدا لأهمية القواعد الفقهية: "وهذه قواعد تضبط للفقيه أصول المذهب وتطلعه من مآخذ الفقه على نهاية المطلب وتنظم عقده المنثور في سلك وتستخرج له ما يدخل تحت سلك"، (الزركشي، 1985: 65 ). .يقول السيوطي بعد أن بين أهمية

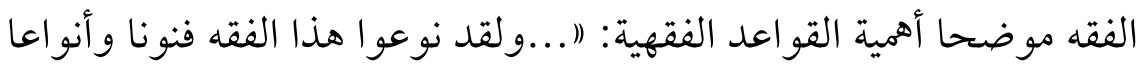
وتطاولوا في استنباطه يدا وباعا وكان من أجل أنواعه : معرفة نظائر الفروع وأشباهها، وضم المفردات إلى أخواتها وإشكالها...). (السيوطي، 1990:

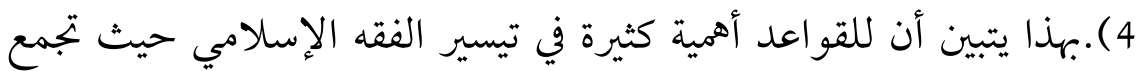
الفروع الكثيرة وتجمع شتاتها في سلك واحد تحت قاعدة واحدة. وفي فهم القو اعد الفقهية تيسير على المفتين و الفقهاء وطلاب العلم ضبط الفقه بأحكامه، لأن حفظ جزيئات وفروع أمر في غاية الصعوبة، أما حفظ القواعد ففيه يسر. و كذلك دراسة القو اعد الفقهية تكون لدى الباحث و الطالب ملكة فقهية تجعله قادرا على التخريج لمعرفة الأحكام الشرعية، وذلك لان القواعد الفقهية وسيلة

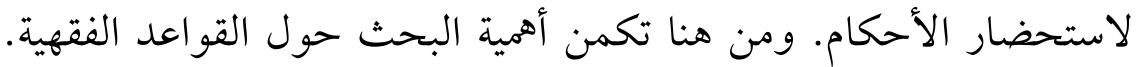
كا أن هذا البحث يتناول القواعد الفقهية التي استخدمها مؤلف كتاب إعانة الطالبين في باب العبادات: الصلاة والصيام والزكاة والحج. فالكتاب مهم في المذهب الشافعي، كما أن الكتاب منتشر بشكل واسع وقاموا بتدريسه في المعاهد الإسلامية في إندونيسيا. فالقواعد الفقهية الخمسة تعتبر من القواعد

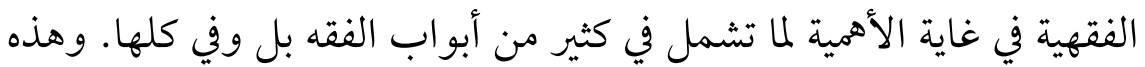
القواعد الفقهية الخمسة قيل عنها: إن الفقه كلهمبني عليها، وهي: الأين الأمور بمقاصدها، اليقين لا يزول بالشك، المشقة تجلب التيسير، الضرر يز ال، وقاعدة العادة محكمة. 


\section{ب. ترجمة العلامة السيد بكري مؤلف كتاب إعانة الطالبين.}

صاحب إعانة الطالبين هو السيد بكري (أبو بكر) بن محمد زين

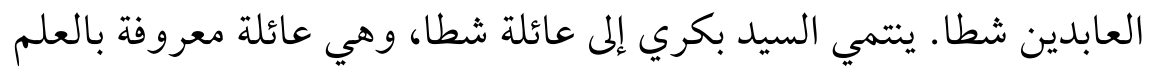
والتقوى كما أن أباه السيد محمد شطا هو كان عالما متبحر اعفيفا متو اضعا إلا أنه توفي و السيد بكري لم يزل مولودا حيث كان عمره ثلاثة أشهر.

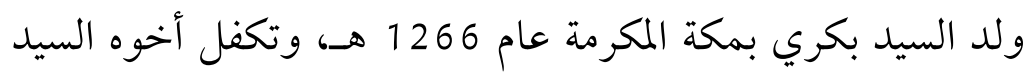
عمر شطا برعايته بعد وفاة أبيهلا السيد محمد زين العابدين شطا. استقر السيد

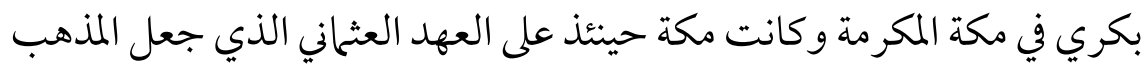

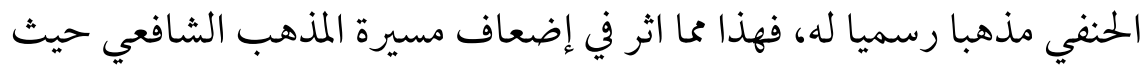

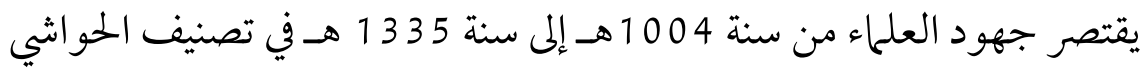
وربها الشروح الخنادمة للمصنفات السابقة مثل منهاج الطالبين للنووي وغيره الفئه

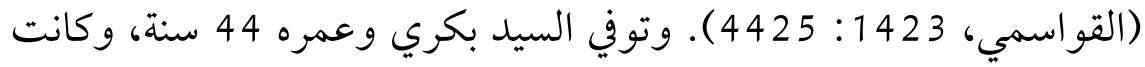

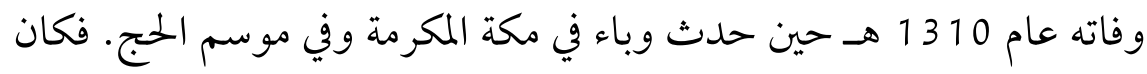

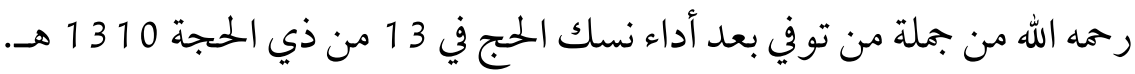
وفي الأعلام أن صاحب إعانة الطالبين هو عثمان بن محمد شطا الدي الدمياطي، أصله

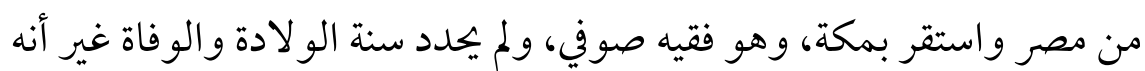

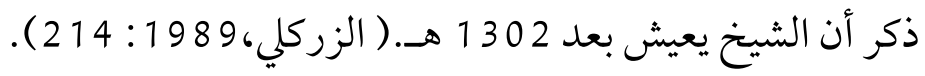

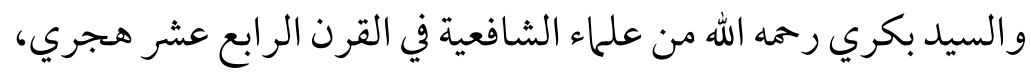

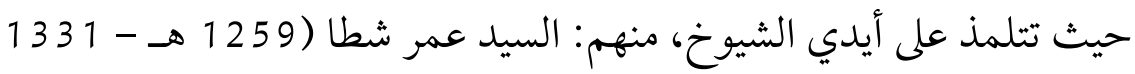

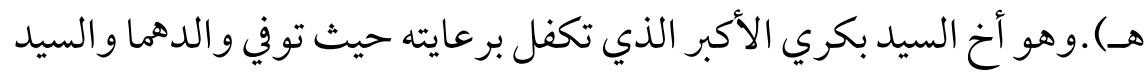

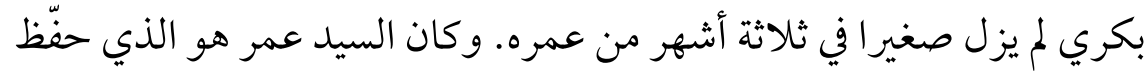

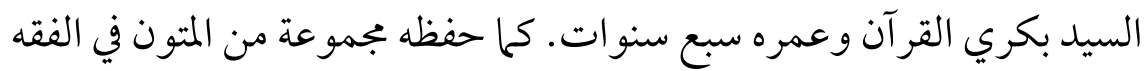

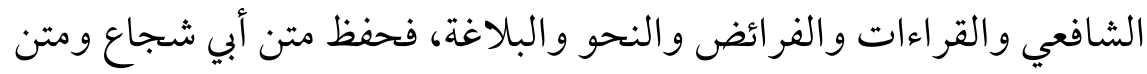

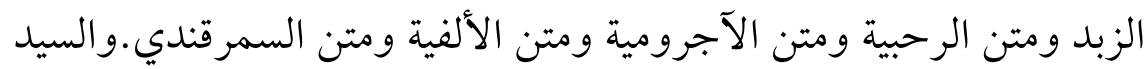


عثمان شطا (1263 هـ - 1295 هـ). وهو أخ السيد بكري الثاني. وكان له إسهام كبير حتى نبغ السيد بكري في العلوم العقلية و النقلية. (المعلمي، 146 14 1 :

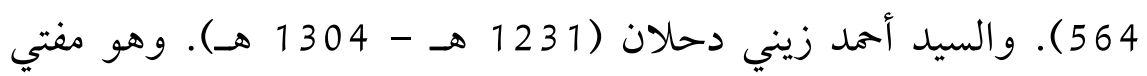
الشافعية بمكة المكرمة. ولد بمكة وتوفي بالمدينة. وكان رحمه الله فقيه ومؤرخ ومشارك في أنواع من العلوم. خرج على يديه علماء أجلاء. وله مصنفات

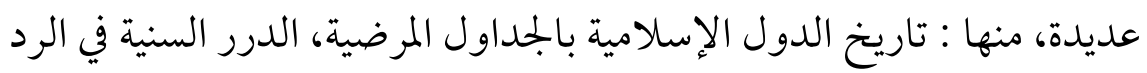
على الوهابية، خلاصة الكلام في بيان أمراء البلد الحرام. (كحالة،د.ت. كما أن له من الدارسين كثيرين تتلمذوا على يده. منهم: الشيخ عبد الحميد قدس (1280 هـ - 1334 م)، السيد عباس بن عبد العزيز المالكي الحسني الإدريسي (1285 هـ - 1253 هـ) هـ، الشيخ سعيد بن محمد اليلني

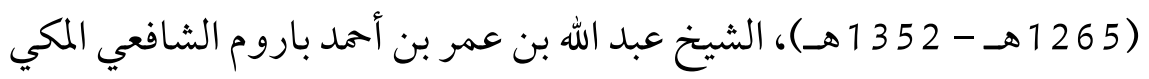

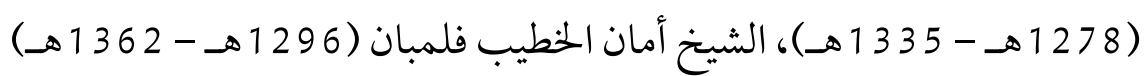

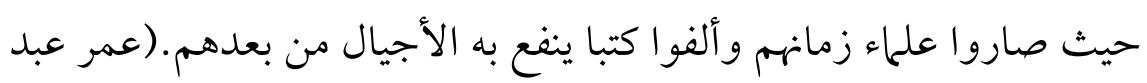

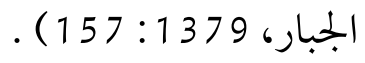

أما عن مؤلفاته، هي: كتاب إعانة الطالبين على حل ألفاظ فتح المعين. وهذا الكتاب وهو عبارة عن حاشية لكتاب فتح المعين للملباري الذي كثر هورئ عليه حواشي وشروح. والكتاب إعانة الطالبين من الكتب المعتمدة في الفقه الشافعي خاصة عن المتأخرين منهم.و كذلك كتاب جو واز العمل العمل بالقول القديم

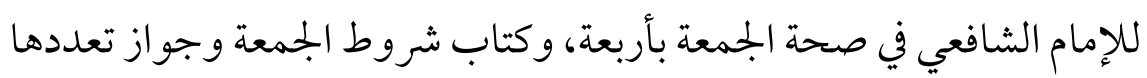
بقدر الحاجة في بلدة واحدة، وكتاب الدرر البهية فيما يلزم المكلف من العلوم الشرعية.وكتاب القول المنقح المضبوط في صحة التعامل ووجوب الزكاة في

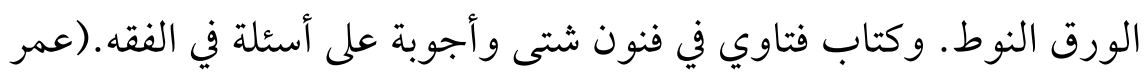

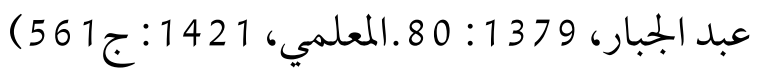


كتاب القول المبرم في الموارث، وكتاب كفاية الأتقياء الأصفياء وهو كتاب في تصوف، كما أنه شرح للمنظومة المسماة هداية الأذكياء إلى طريق الأولياء للشيخ زين الدين المليباري، وكتاب نفحة الرحمن في مناقب السيد أحمد زيني دحلان، وكتاب قصة الإسراء والمعراج. وللشيخ السيد بكري كذلك ونك مؤلفات خطية، وهي :تفسير القر آن الذي وصل فيه إلى سورة المؤمنون، حاشيته على تحفة المحتاج بشرح المنهاج وصل فيها إلى باب البيوع، حاشيته على عمدة

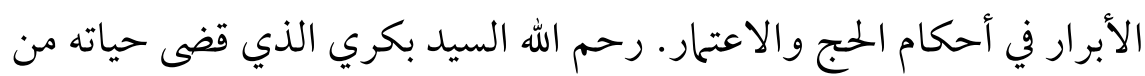
أجل خدمة العلم و التعليم ونفعنا بعلمه.

1 ـ تعريف القواعد الفقهية والفرق بينها وبين المصطلحات المتشابهة

فالقو اعد الفقهية مركب من كلمتين: القواعد و الفقهية. القاعدة لغة

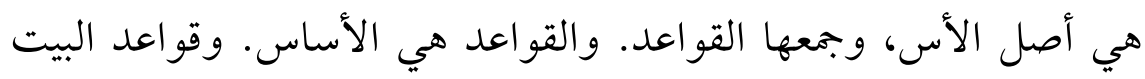
أساسه. وقو اعد الهودج خشبات أربع معترضة في أسفله تركب عيدان الهودج

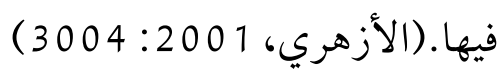

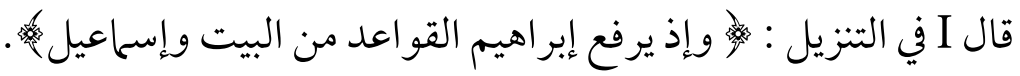
[البقرة: 72 ] 12 و القاعدة في الاصطلاح، هناك عدة تعاريف:قضية كلية منطبقة على جميع جزئياتها. ومنهم من عرفها قضية كلية يتعرف منها أحكام جزئياتها.

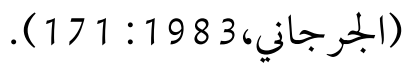

وأما القاعدة عند الفقهاء أو ما نسميه بالقاعدة الفقهية، وهي ما يعنينا هنا في هذا البحث فإن الفقهاء قد اختلفوا في تعريفها، نظر الاختلافهم باعتبار هل القاعدة أمر كلي أو أمر أكثري؟. فمن عرف القاعدة باعتبار أنها أمر كلي

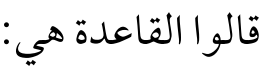
أصول و مبادئ كلية تصاغ في نصوص موجزة تتضمن أحكاما تشريعية عامة في الحو ادث التي تدخل تحت موضوعها. (شلبي، 1985 : 1966 ). ومنهم 
من يرى أن القاعدة أمر أغلبي فيكون القاعدة الفقهية هي حكم أكثري لا

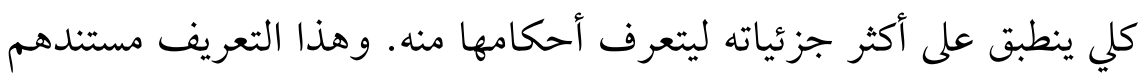

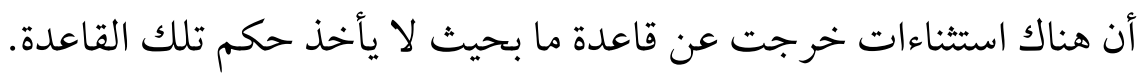

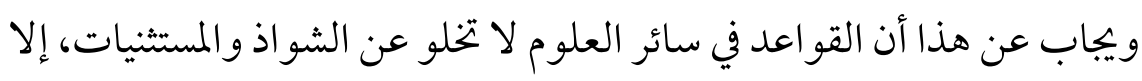
أنها لا تغض من شأنها.

هناك قو اعد فقهية كالقواعد الأساسية الخمس، فالمستثنيات فيها قليلة

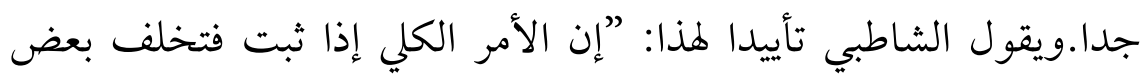

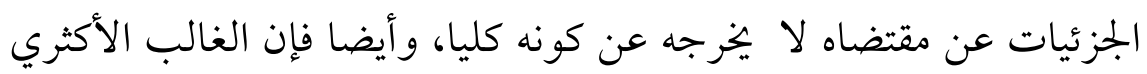

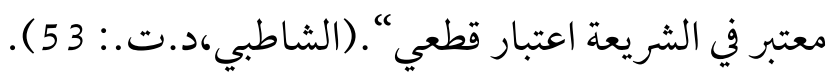
ومن المناسبة هنا ذكر الفرق بينها وبين تلك المصطلحات المشابهة لها،

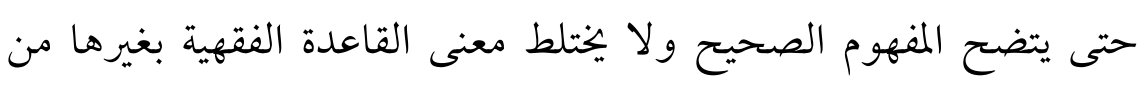

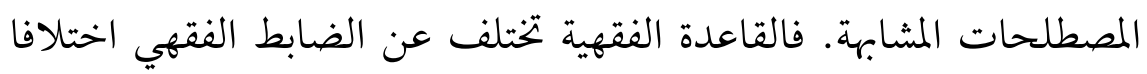

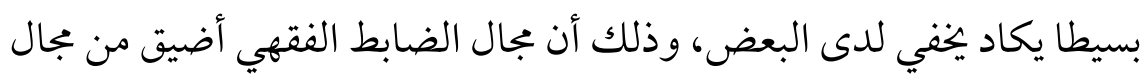

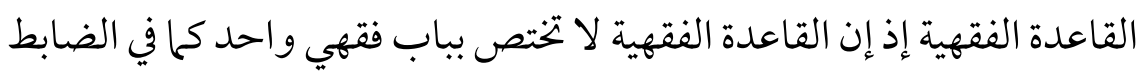

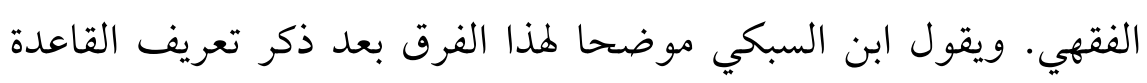

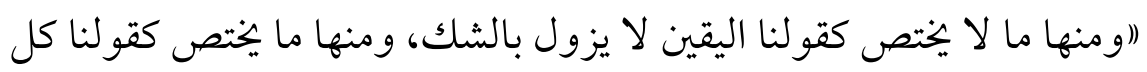

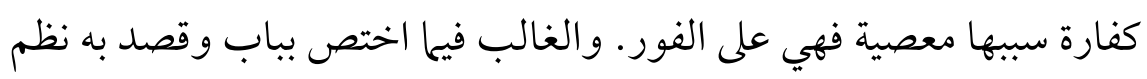

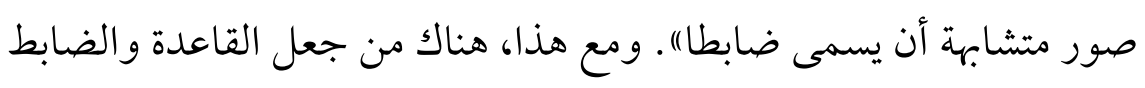

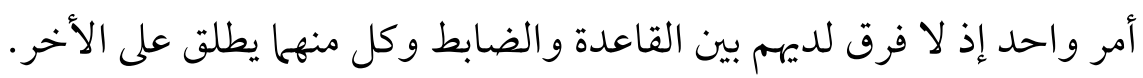
وذلك أن العموم والشمول أمر نسبي. (الباحسين، وكذلك القاعدة الفقهية تختلف عن القاعدة الأصولية، والفرق بينها

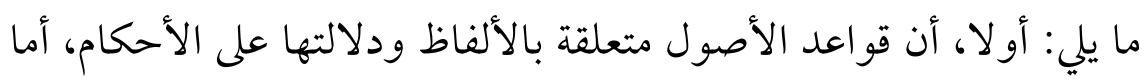

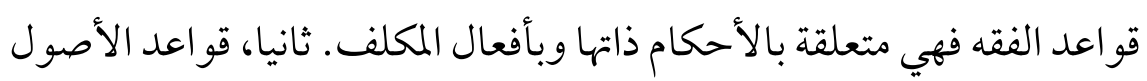
هي وسيلة المجتهد في استباط الأحكام الشرعية، أما قواعد الفقه فهي عبارة 
عن جمموعة الأحكام المتشابهة التي ترجع إلى علة واحدة تجمعها. ثالثا، قواعد

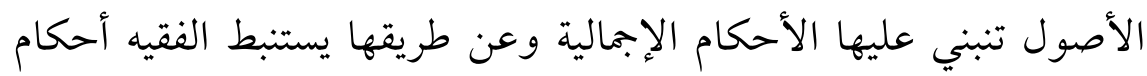
المسائل الجزئية من الأدلة التفصيلية، أما قواعد الفقه فهي تعلل بها أحكام

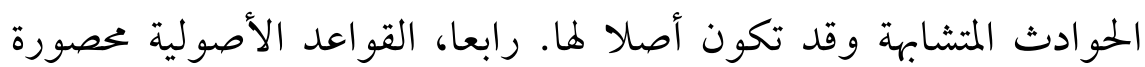
العدد في أبو اب الأصول ومو اضعها، بخلاف القواعد الفقهية فهي كثيرة غير مصورة، منثورة في كتب الفقه والفتاوى. خامسا، القواعد الأصولية تنطبق تنطبق على جميع جزئياتها بخلاف القو اعد الفقهية فإنها قد تكثر فيها استثناءات. سادسا، القواعد الفقهية متأخرة في وجودها عن الفروع لأنها جمع الفروع في علة واحدة بخلاف القو اعد الأصولية فإن وجودها متقدمة عن الفروع لأنها وسيلة لاستنباط الحكم الشرعي.(البورنو، 2002: 20: الباحسين: 1998

وبعد ذكر هذه الفروق، نشير إلى أمر هام، وهو أن هناك قو اعد مشتركة بينها و متداخلة وذلك لاختلاف النظر إلى القاعدة حيث ينظر إليها من جهتين : باعتبار أنها دليلا شرعيا من جهة، وباعتبار أنها فعل للمكلف من جهة أخرى.

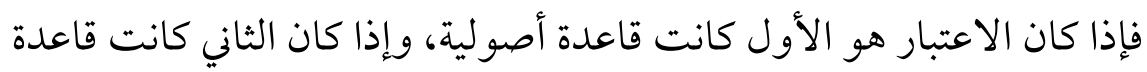
فقهية. والمثال على ذلك : سد الذرائع فإذا قيل: كل مباح أدى فعله إلى حرام فهو حرام سدا للذريعة، فهو يكون قاعدة فقهية. وإذا قيل :الدليل المثبت للحر ام مثبت لتحريم ما أدى إليه فهي قاعدة أصولية.

\section{2. أهمية القواعد الفقهية ومر احل تطورها}

وأما عن أهمية القو اعد الفقهية قد أشرت الباحثة في المقدمة وهي تيسير الفقه الإسلامي حيث تجمع الفروع الكثيرة وتجمع شتاتها في سلك واحد تحت قاعدة واحدة. وفي فهم القو اعد الفقهية تيسير على المفتين والفقهاء وطلاب

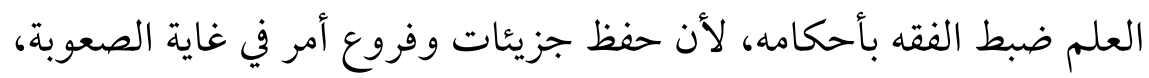


أما حفظ القو اعد ففيه يسر ـ وكذلك دراسة القواعد الفقهية تكون لدى الباحث

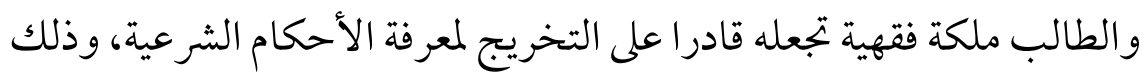

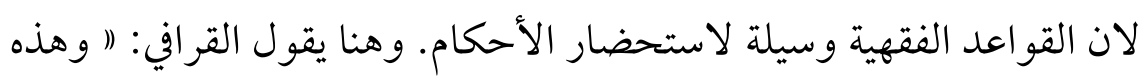

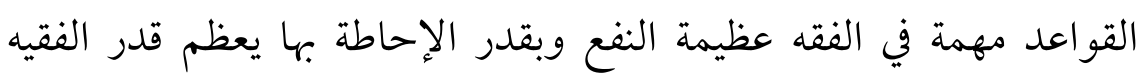

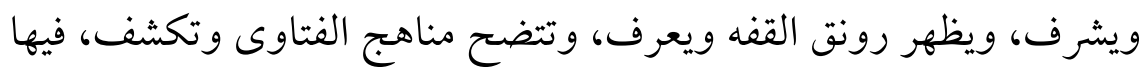

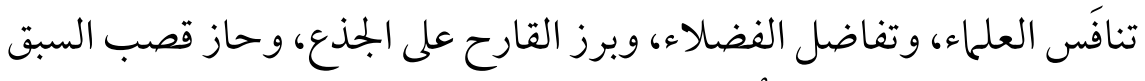

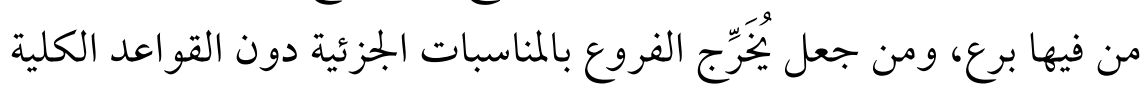

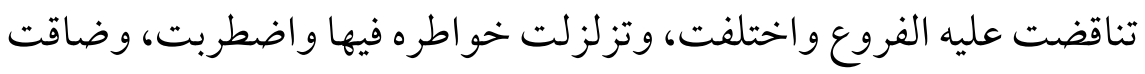

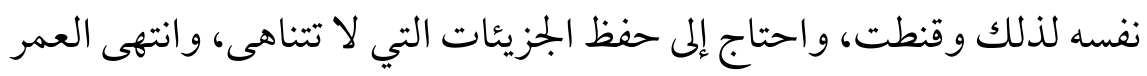

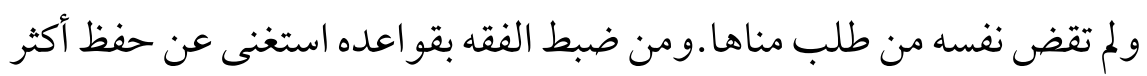

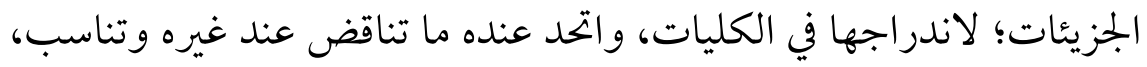

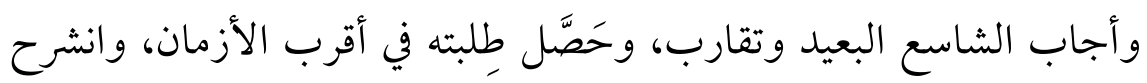

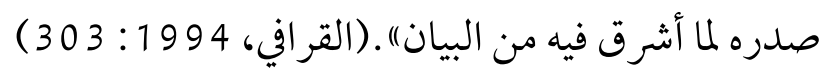
وقد مرت القو اعد الفقهية على أطو ار عديدة حيث تبدأ المرحلة بمر حلة البيال

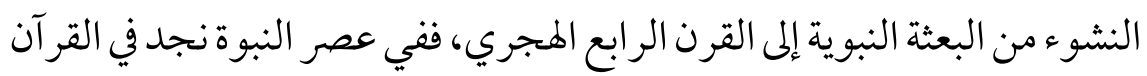

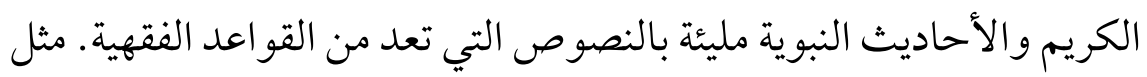

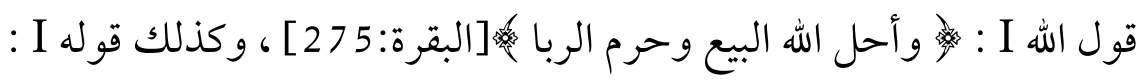

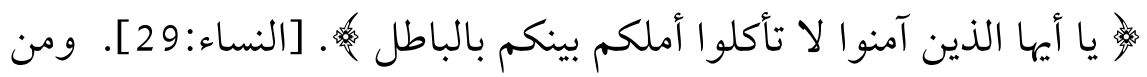

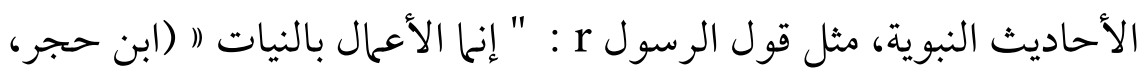

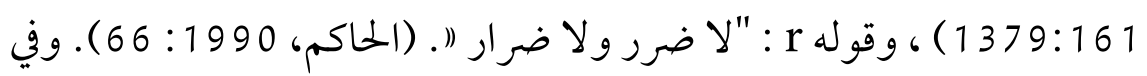

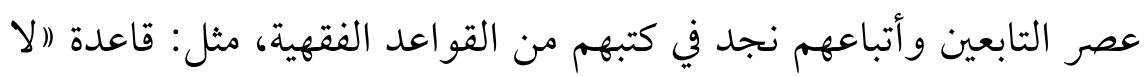

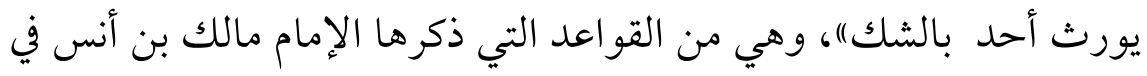

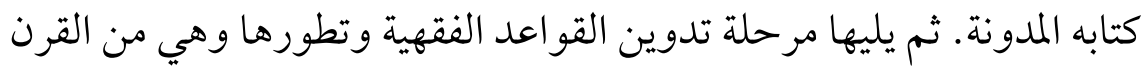

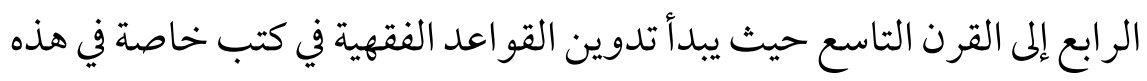


المرحلة على يد الفقه الحنفي أبي الحسن الكرخي الذي ألف رسالة في القواعد الفقهية وتسمى هذه الرسالة بالأصول الكرخي"). وفي هذه الرسالة لم تكن هناك قواعد فقهية فقط، بل اختلط بالقواعد الأصولية كذلك. ومن المالكية الذي يهتم بالقو اعد الفقهية في هذه المرحلة هو محمد بن الحارث الخشني الذي ألف كتابا يسمى (أصول الفتيا)، ، وهذا الكتاب فيه القواعد الفقهية والأصولية كذلك. وفي هذه المرحلة كذلك، ظهرت عدة المؤلفات في القواعد الفقهية، منها: قواعد الأحكام في مصالح الأنام للشيخ عز الدين بن عبد السلامٍ أنوار البروق في أنواء الفروق للقرافي، القواعد الكبرى و القواعد الصغرى للطوفي. وغيرها كثيرة. ثم تأتي المرحلة التالية وهي مرحلة استقرار القواعد الفي الفقهية من

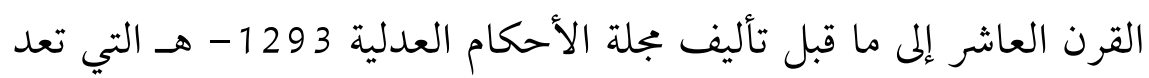
هذه المرحلة مرحلة الاستقرار للقو اعد الفقهية حيث تميزت مباحثها وحددت القواعد و الضو ابط الفقهية وتميزت عن غيرها. وهناك عدة كتب التي ظهرت في هذه المرحلة، ومن أشهرها : (الأشباه و النظائر) للسيوطي الشافعي، وله كتاب أخر "(شوارد الفوائد في الضو ابط و القو اعد)، و كتاب ("منظومة المنهج المنتخب)"

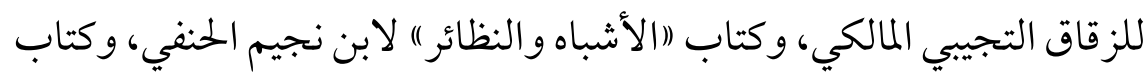

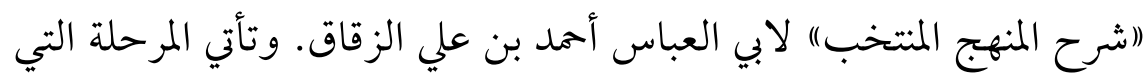
بعدها هي مرحلة النهضة العلمية في مجال القواعد الفقهية. وهي مرحلة أخيرة التي تبدأ من نهاية القرن الثالث عشر الهجري إلى أيامنا هذه. ويحدد نهاية القرن الثالث عشر الهجري لوجود معلم مهم وهو ظهور بجلة الأحكام العدلية حيث إنه عرضت القو اعد على شكل مو اد. وظهرت أعمال في هذه المرحلة وهي:

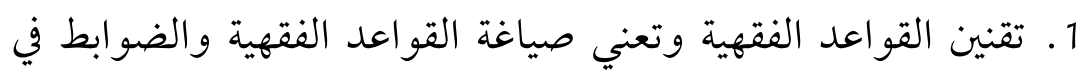
صورة مبادئ عامة مرتبة في صورة مو اد ومبوبة بحسب الموضوعات. وفي هذا تسهيل على القاضي في الكشف على الحكىم الشرعي في المسألة

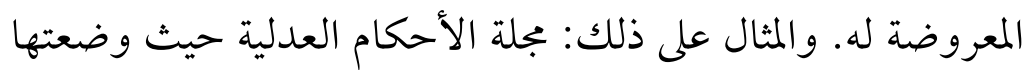


لجنة من العلماء في الدولة التركية، مجلة الأحكام الشرعية على مذهب الإمام أحمد بن حنبل للشيخ أحمد بن عبد الله القاري. 2. تحقيق طائفة من كتب التراث في القواعد الفقهية. ومن أمثلته : المثثور

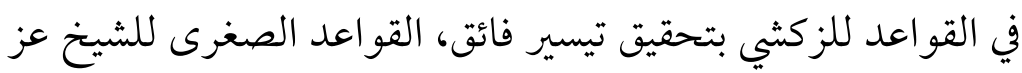

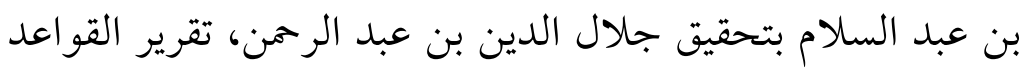
وتحرير الفو ائد لابن رجب بتحقيق مشهور حسن السلمان.

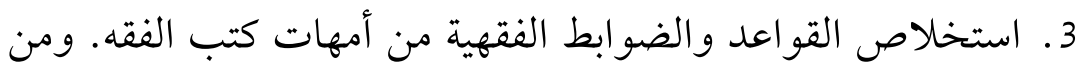

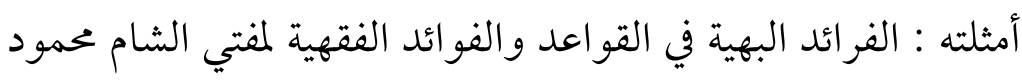

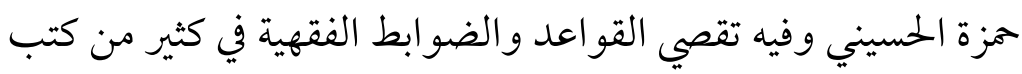

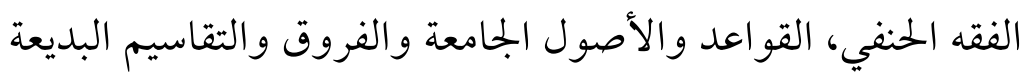

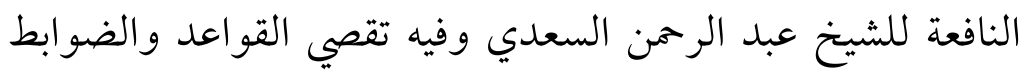
الفقهية في كثير من كتب الفقه الحنبلي. 4. رصد القواعد الفقهية وإحصاؤها وترتيبها. ومن أمثلته: كتاب قو اعد العد

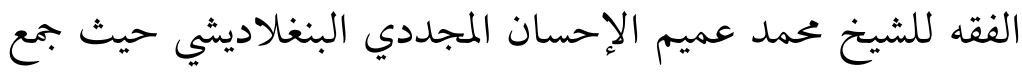
426 قاعدة مرتبة حسب حروف المعجم، موسوعة القواعد الفقهية

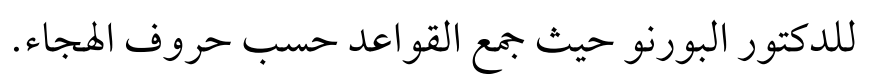

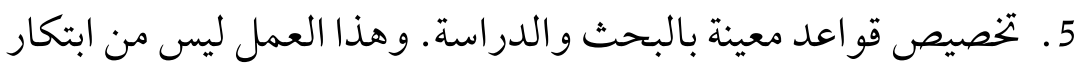
العلماء المعاصرين، وانما قام به كذلك العلماء السابقون كما فعل أبو

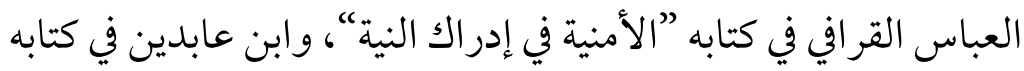

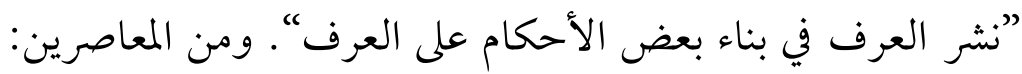

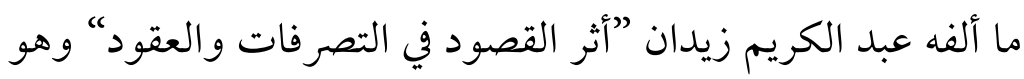

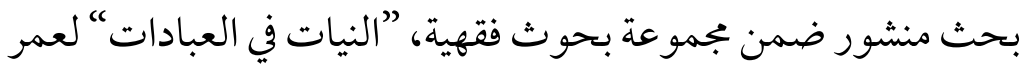
الأشقر وهو عبارة عن رسالة دكتوراة. وكذلك توجد مؤلفات مستقلة بالدراسة حول قاعدة المشقة تجلب التيسير وغيرها من القو اعد. 


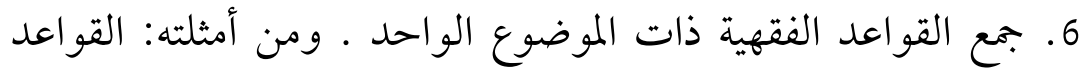

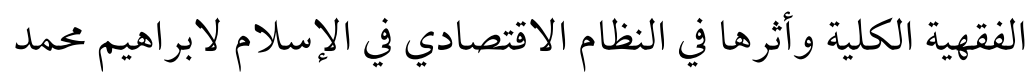

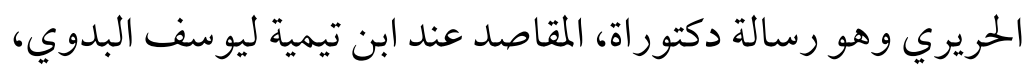

$$
\text { عبارة عن رسالة دكتوراة. }
$$

7. الاهتحام بالمداخل لعلم القواعد. ومن أمثلته: القو اعد الفقهية للدكتور

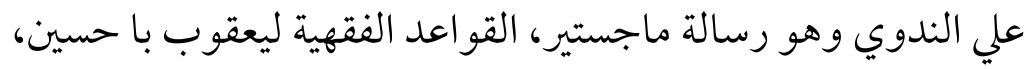
المدخل الفقهي للشيخ مصطفى الزرقاء.

\section{3. أنواع القواعد الفقهية}

القواعد الفقهية لها أنواع بحسب النظر إلى الجهة المختلفة واعتبارات

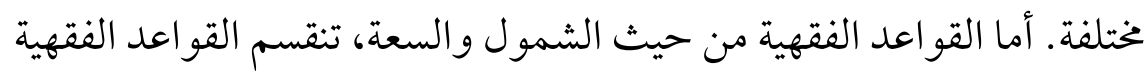

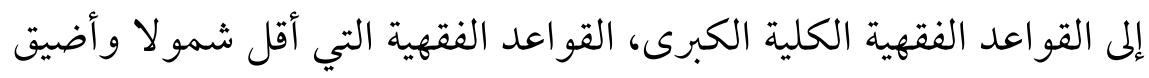

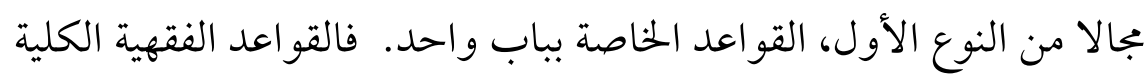
الكبرى وهي القواعد التي ترجع إليها مسائل كثيرة من جميع أبواب الفقه.

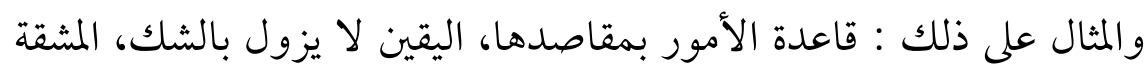

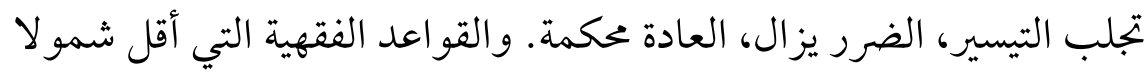

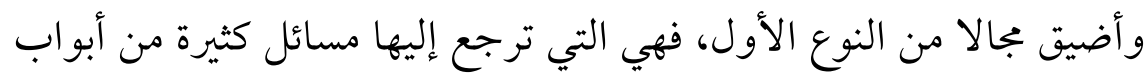

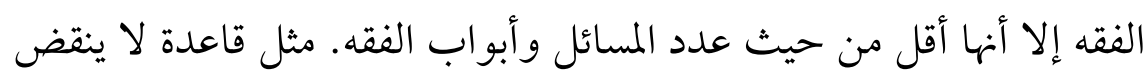

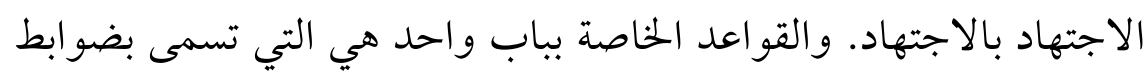

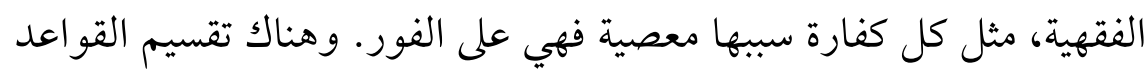

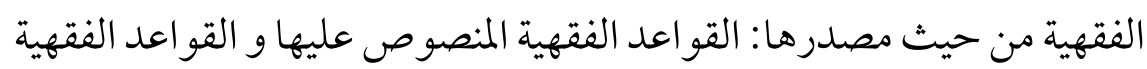

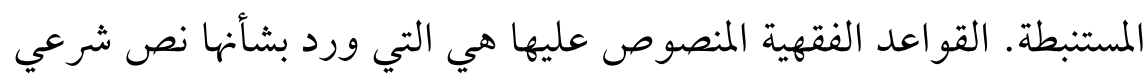

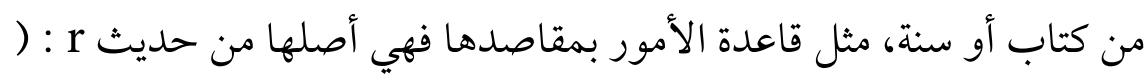

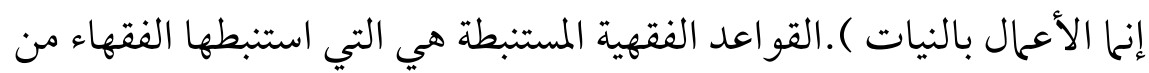

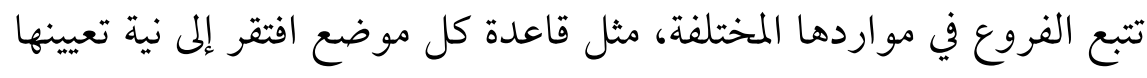




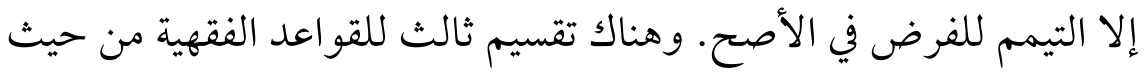
الاتفاق والاختلاف: القواعد الفقهية المتفق عليها بين المذاهب والقواعد التاعد

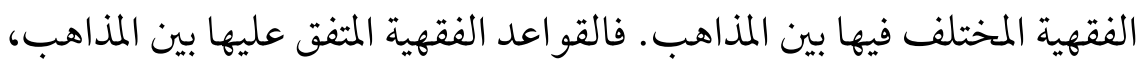

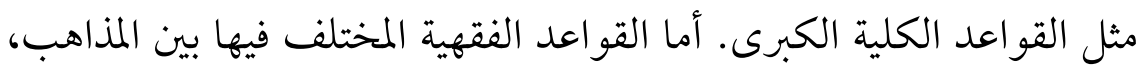
مثل قاعدة ما حرم استعاله حرم اتخاذه، قاعدة خختلفة بين الشافعية والحنفية. 4. القواعد الفقهية الخمسة في باب العبادات من كتاب إعانة الطالبين للسيد بكري

وهذه القواعد الفقهية الخمسة، كثيرا ما يعبر عنها بالقواعد الكبرى

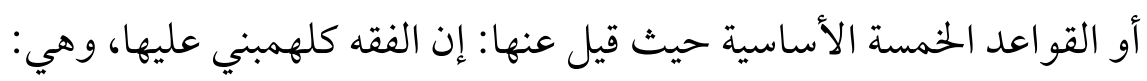

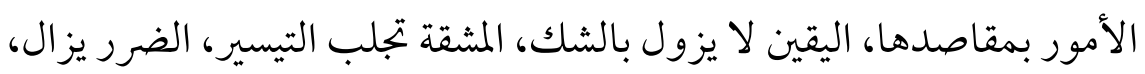

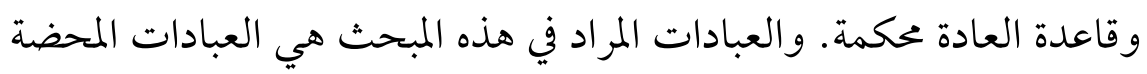

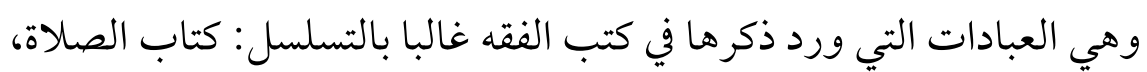

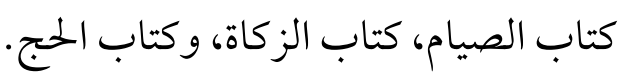

القاعدة الأولى: قاعدة الأمور بمقاصدها

تعتبر هذه القاعدة من إحدى القواعد الكلية الكبرى التي تندرج تحتها

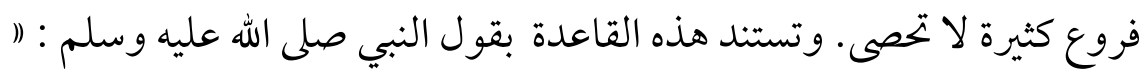

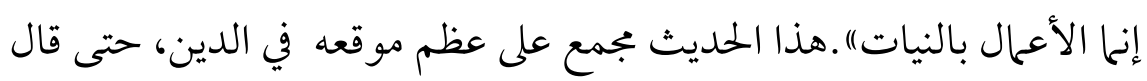

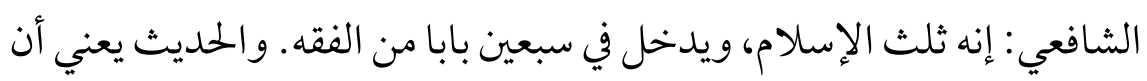

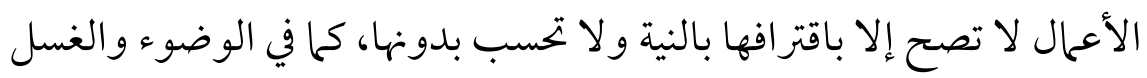

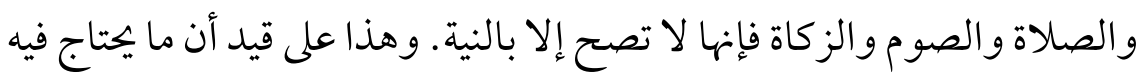

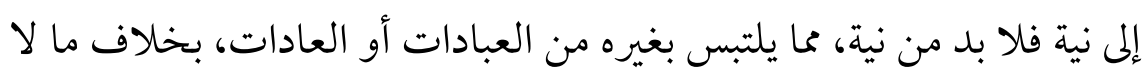

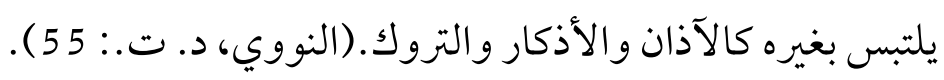


ومن التطبيقات على هذه القاعدة في باب الصلاة من كتاب إعانة

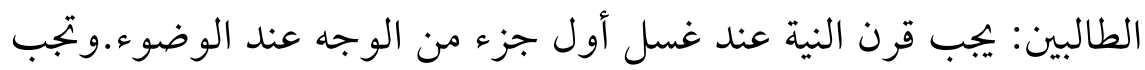

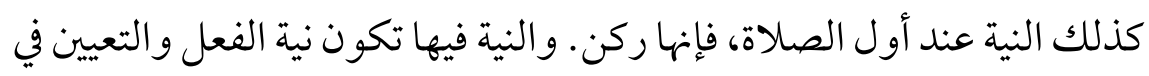
أي الصلاة وكذلك نية الفرضية.وبالاضافة إلى أن النية تجب عند سجود السهو وتجب مقارنتها للشروع في السجود. و أما في باب الزكاة من نفس الكتاب فإن تطبيقاتها هي : تجب النية عند أداء الزكاة للمزكي، ولا يشترط النطق بها،كما أنه لا يشترط التعرض لفرضية

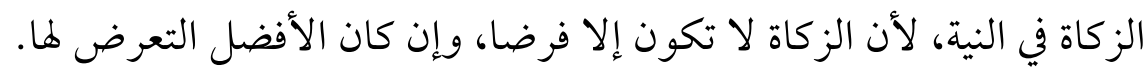

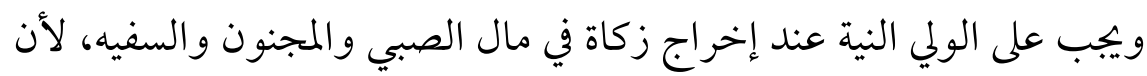
النية تعذرت من هؤلاء فينوي عنه وليهم. وفي باب الصيام، من أمثلة تطبيقات قاعدة الأمور بمقاصدها هي: وجوب نية عند إرادة صوم يوم رمضان، وهذه النية لا بد أن تكون ليلا، وهو

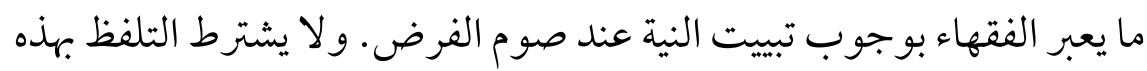

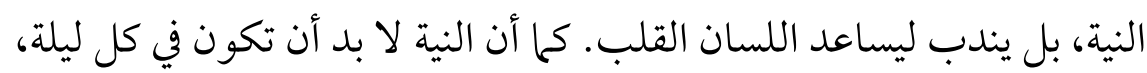

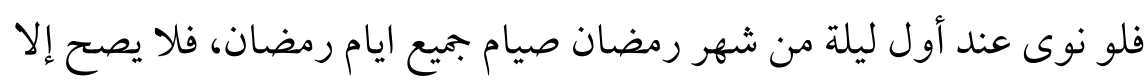
صوم أول يوم رمضان.

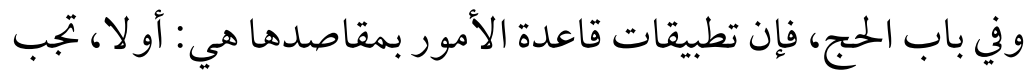
النية عند الدخول في الحج وذلك عند الإحرام به، ولا يصح الإحرام إلا بالنية،

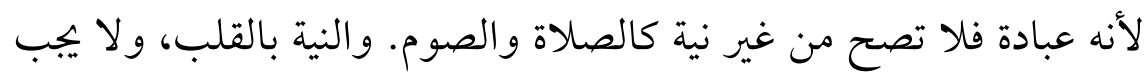

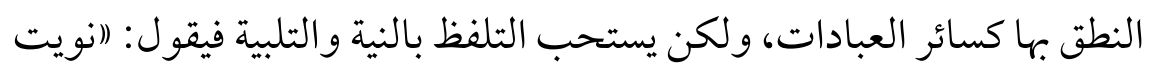
الخج وأحرمت به لله I، لبيك اللهم لبيك، لبيك لا شريك لك لبيك، إن الحمد

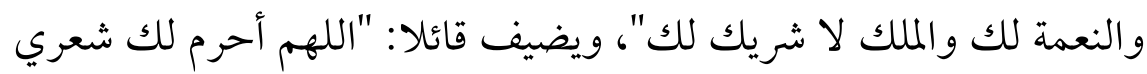
وبشري وعظمي ودمي لله رب العالمين لا شريك لك". و التلفظ بالنية مستحب لتساعد القلب وتؤكد ما فيه. فان لم ينو في القلب وتلفظ لم يصح إحر امه، وان 
نوى في قلبه دون التلفظ به صح إحر امه.و إن لبى ولكن لم ينو الإحرام، فهل

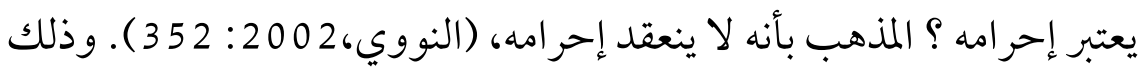

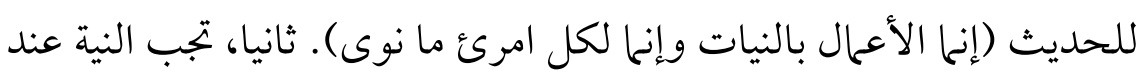

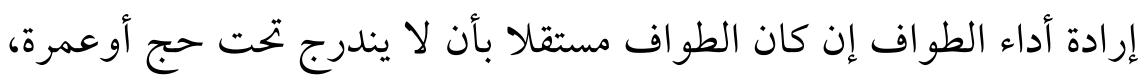
أما إن كان الطو اف يندرج تحت نسك حج أو عمرة، فتكون النية هنا النا مستحبة.

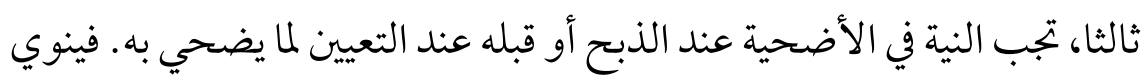

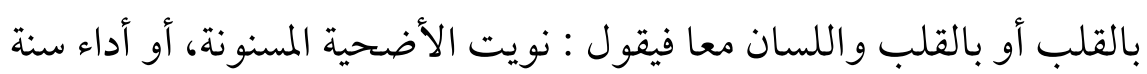

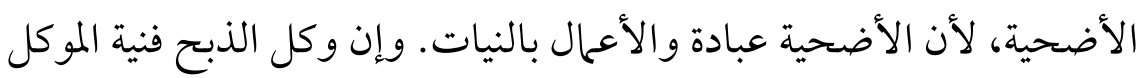

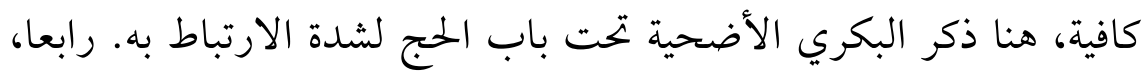

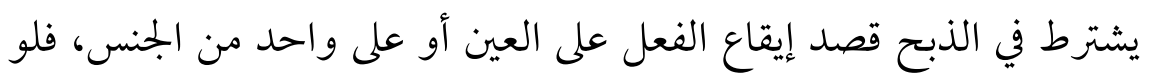

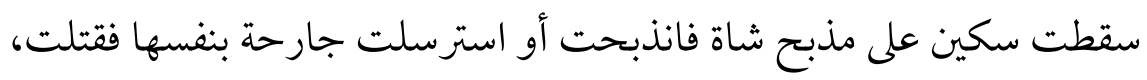

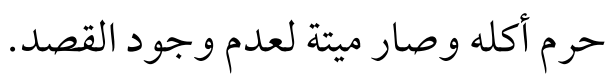

\section{القاعدة الثانية: اليقين لايزول بالثك}

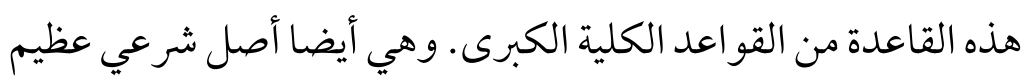

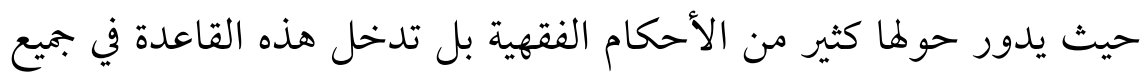

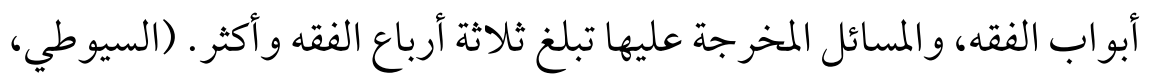

واليقين لغة : العلم وإزاحة الشك وتحقيق الأمر.وفي الاصطلاح:

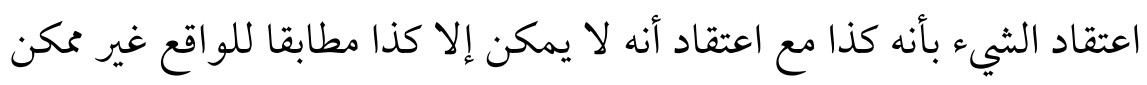

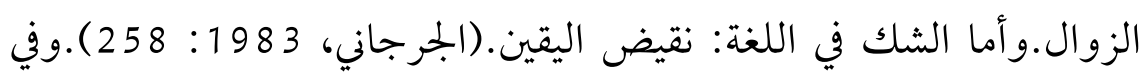
الاصطلاح : التردد بين القضيتين بلا ترجيح لأحدهما على الآخر عند الشاك. الثراك.

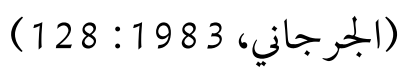

ومعنى قاعدة (اليقين لا يزول بالشك) أن اليقين هو الأصل المعتبر ولا

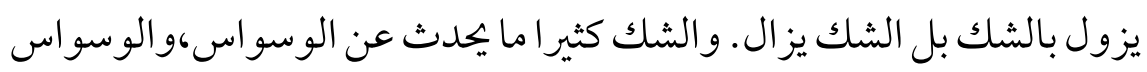


من الشيطان. والوسواس داء عضال، يحدث كثيرا في العبادات من الوضوء

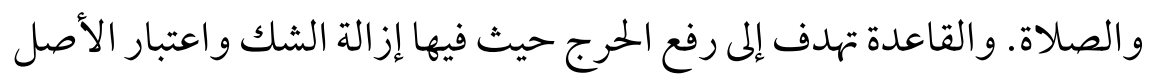

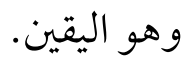

تستند هذه القاعدة إلى أحاديث نبوية، هي حديث عبد الله بن زيد

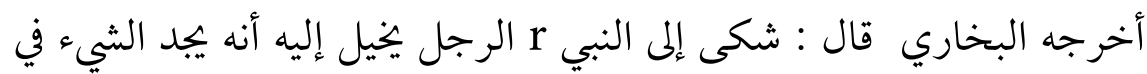

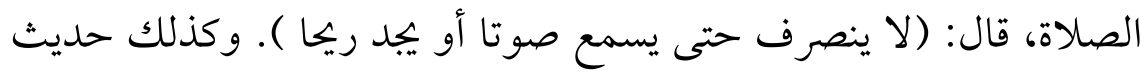

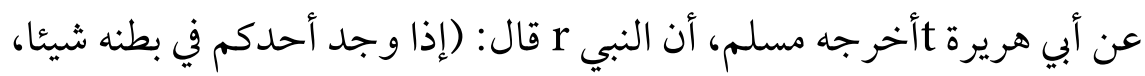

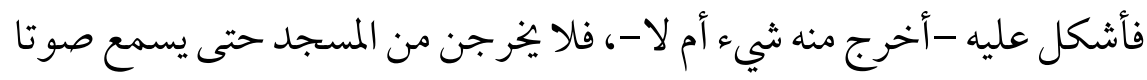

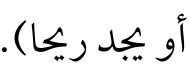

ومن تطبيقات القاعدة في باب الصلاةكتاب إعانة الطالبين، ما يلي:

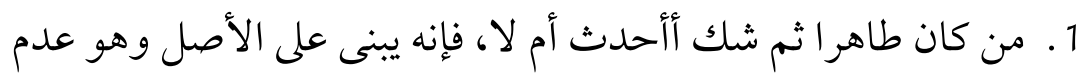

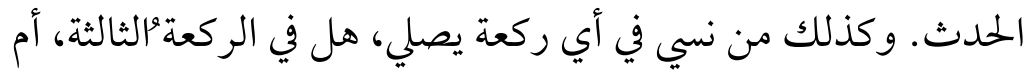
في الر ابعة، بني على الأقل، لأنه الأصل.

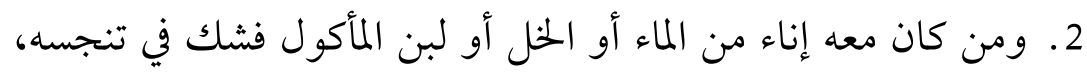

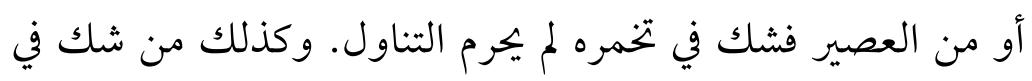

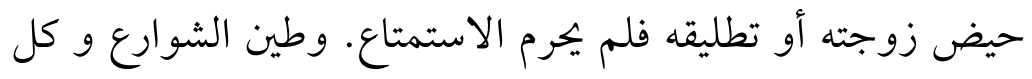

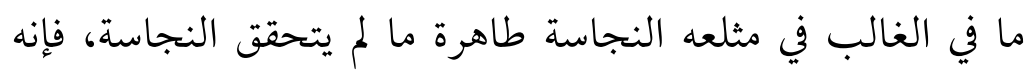

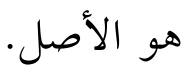

أما تطبيقات القاعدة في باب الزكاة فإن المؤلف لم يتطرق إليها في هذا

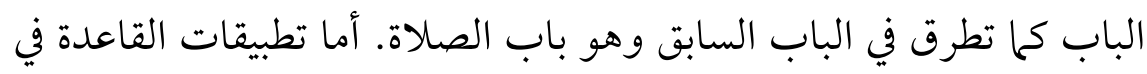

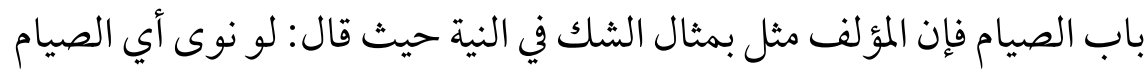

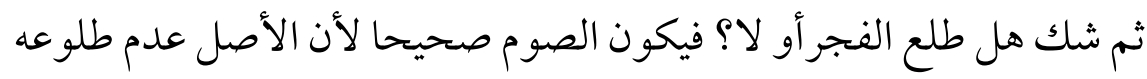
فلا يبطلها نحو أكل وغيره.ولو ظن بقاء الليل أو شك بقاؤه، فإنه ييوز الأكل 
لأن الأصل بقاء الليل. كما مثل هذه القاعدة في رخص الشارع للمسافر مسافة القصر الفطر ومن كان مريضا خاف بطء برءهاء الأهل

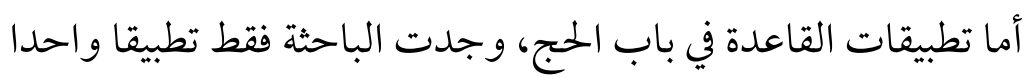

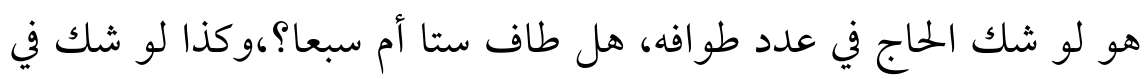

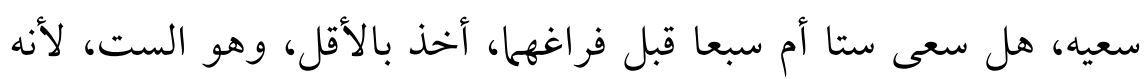
هو المتيقن.

القاعدة الثالثة: المثقة بجلب التيسير

القاعدة واضحة في معناها، وهي أن المشقة سبب للتيسير و التخفيف في

$$
\text { أحكام الشريعة. }
$$

و المشقة في اللغة من الشق بكسر الشين والشدة في القاف، وهي الجهاء

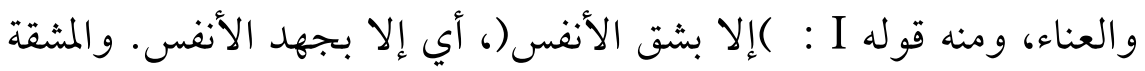
كذلك من مصدر من فعل شق أي ثقل، يقال شق علي ذلك الأمر : أي ثقل علي.

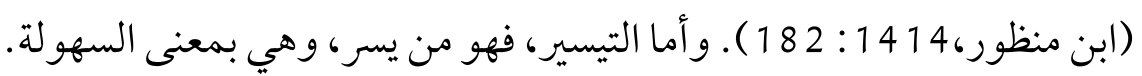

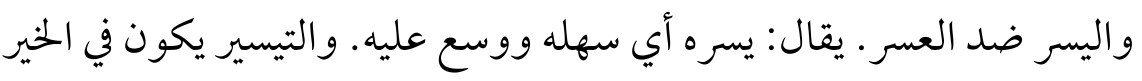

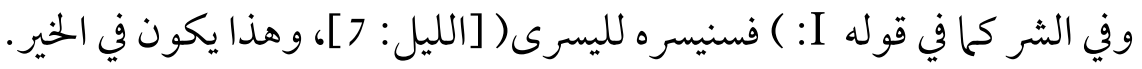

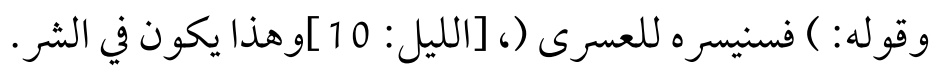

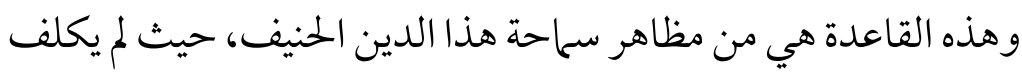

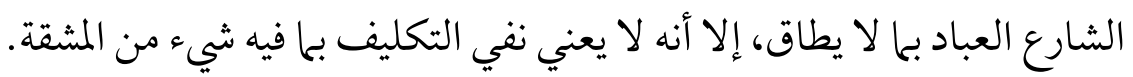
والمشقة تنقسم إلى ضربين:

الضرب الأول : المشقة التي لا تنفك عنها العبادة -غالبا-، وهذه

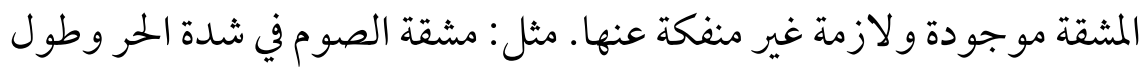

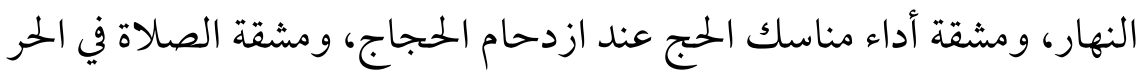


والشتاء، ونحوها. وهذه كلها لا أثر لما في إسقاط العبادات ولا تحفيفها، إذ لو أثرت لفاتت مصالح الطاعات،والعبادات في جميع الأوقات أو في غالبها. الضرب الثاني: مشقة منفكة عنها العبادة. وهي على ثلاث مراتب:

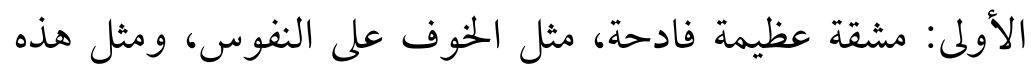

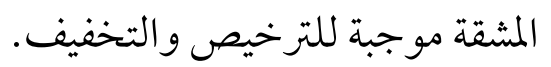

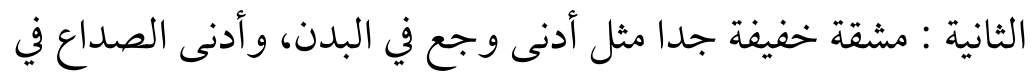

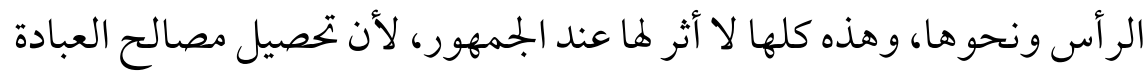

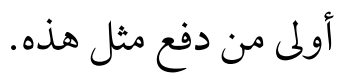
الثالثة : مشقة متوسطة بين المرتبتين السابقتين. فالذي دنا من المرتبة

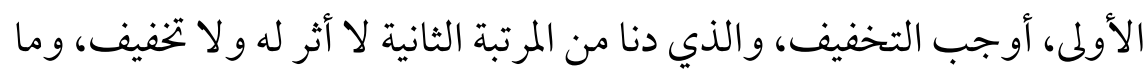

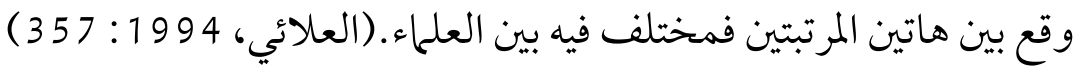

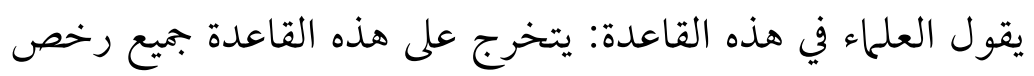

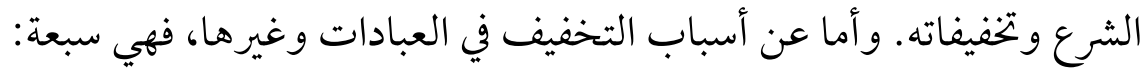

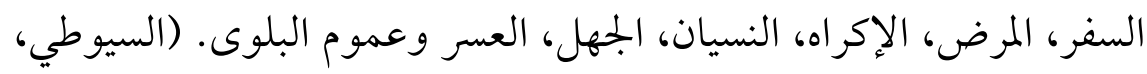
.) (196:2004

هذه القاعدةأدلة كثيرة. منها من القرآن ومنها من السنة النبوية. أما

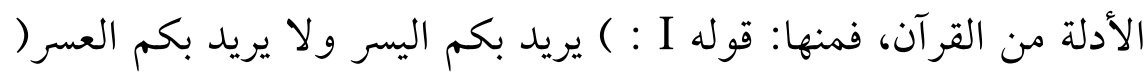

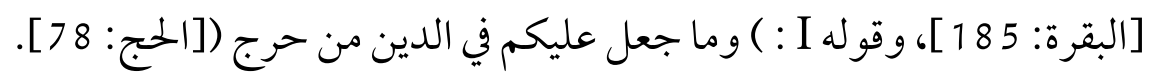

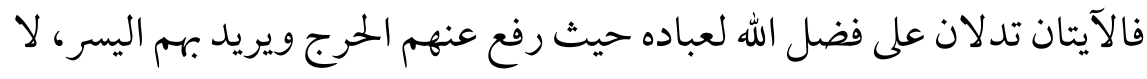
العسر • ورفع الحرج هو مقصد عظيم من مقاصد الشريعة.

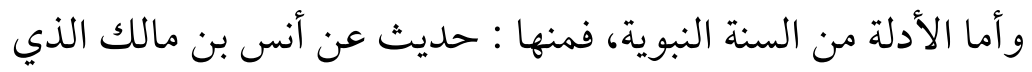

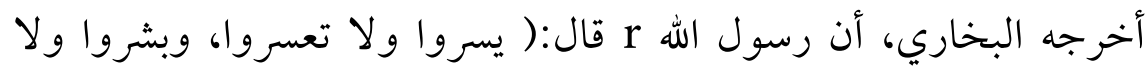

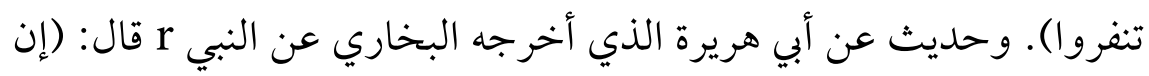


الدين يسر، ولن يشاد الدين أحد إلا غلبه، فسددوا وقاربو او أبشروا، واستعينوا بالغدوة والروحة وشيء من الدلجة). و الحديثان فيها بيان سلاحة الدين، وأنه دين يسر، وأن من هدى النبي r التيسير و التبشير. أما التطبيقات على هذه القاعدة في باب الصلاة من هذا الكتاب: رخص الشارع كثيرا من رخص في السفر، كجمع وقصر الصلوات بشروط معتبرة، لما في السفر من المشقة غالبا.

وكذلك من تطبيقات قاعدة عموم البلوى وهي قاعدة اشتملت عليها قاعدة اليقين لايزول بالشك:عدم اشتر اط تنظيف وسخ ما تحت ظفر في الوضوء إن عسر تنظيفه، ويصح الوقوف في الصلاة على الأرض التي عليها ذرق الطيور، ولكنه بشروط: ألا يتعمد الوقوف عليه، وألا تكون رطوبة، إلونه ومشقة الاحتراز منه، ويعفى عن بعرة الفأرة إذا وقع في مائع لعموم البلوى. ويعفى عن قيء الرضيع الذي أصاب ثدي الأم لمشقة الاحتراز.ويعفى عا بعا تلقيه الفئر ان في حياض الأخلية لعموم البلوى.

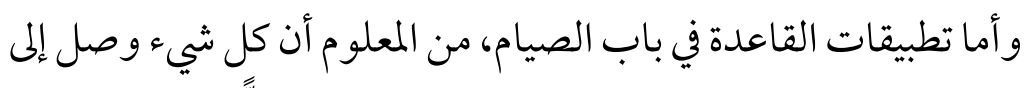

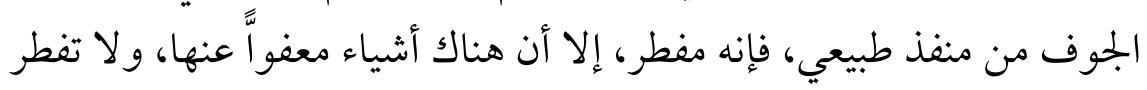
الصائم، مثل الذباب وغبار الطريق وغربلة الدقيق ونحوها لو وصلت إلى جوف الصائم بلا قصد من الصائم لعموم البلوى ولمشقة الاحتراز عنها.وكذلك لو

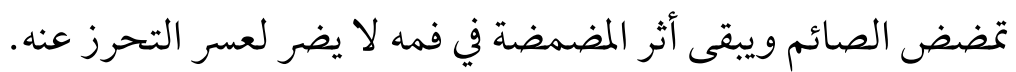
ولو أن شخصا تدمي لثثه ويجرى الدم دائم) أوغالبا، فحينئ يكفي بصقه ويعفي عن أثره ولا يفطر إذا ابتلعه، لعموم البلوى ومشقة الاحتراز. وقاعدة عموم البلوى داخلة تحت قاعدة المشقة تجلب التيسير. أما تطبيقات القاعدة في باب الزكاة فإن المؤلف لم يتطرق إليها كما تطرق في البابين السابقين وهو باب الصلاة و الصيام. 
أما تطبيقات القاعدة في باب الحج فإنه يشترط في الطو اف الطهارة عن

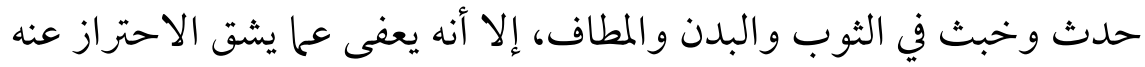
في المطاف من نجاسة الطيور وغيرها إن لم يتعمد المشي عليها ولمتكن رطوبة فيها

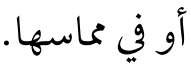

القاعدة الر ابعة: الضر ريزال

هذه القاعدة تعد من القواعد الكليات الكبرى حيث ينبني عليها كثير

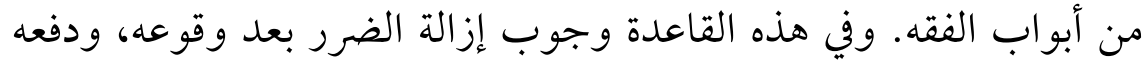

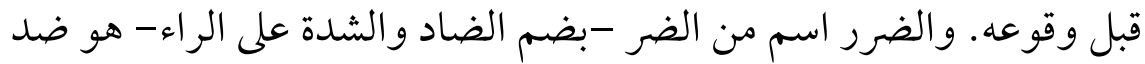

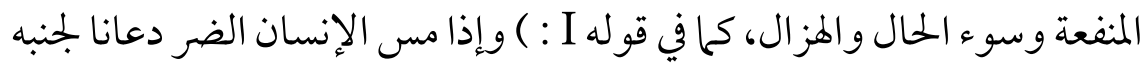

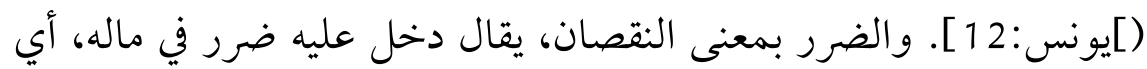

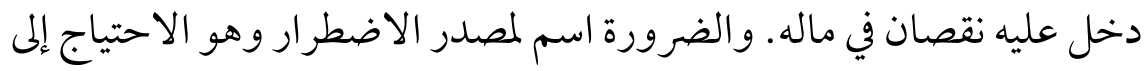

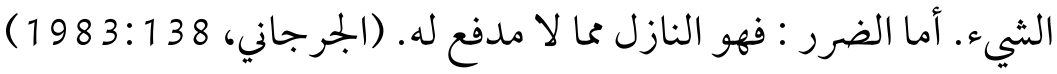
وأصل هذه القاعدة، قوله rالذي أخرجه الحماكم وقال حديث صحيح:

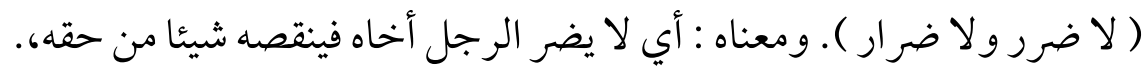

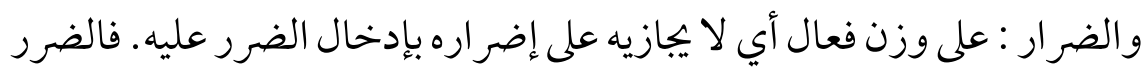
يكون من فعل الواحد، والضرار من فعل الاثنين. والضرر : ابتداء الفعل،

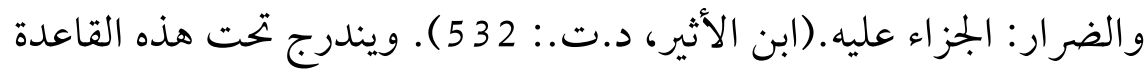

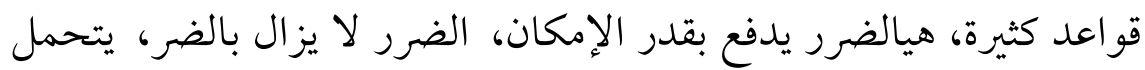

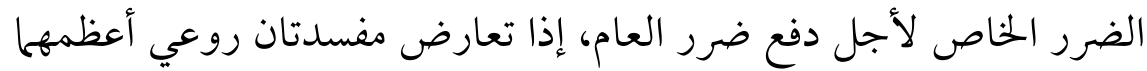

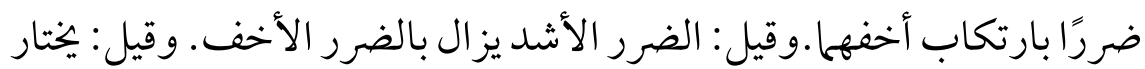

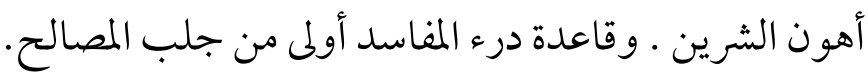
إلا أن المؤلف فقط أشار إلى أهمية هذه القاعدة ولم يذكر تطبيقات هذه البه

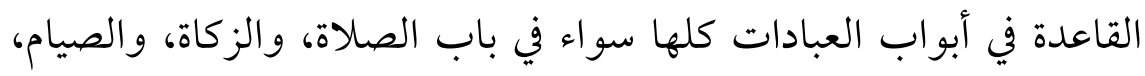
والحج. 
وكثر ما يقال أن قاعدة (الضرر يزال)" وقاعدة (المشقة تجلب التيسير)" هما قاعدتا التيسير الشرعي والرخص الشرعية، وأن روح الشريعة السمحة تتجلى فيها، حيث تعدان الحجاب الواقي من دخول العنت على المكلف، والحاجز بين المكلف وحمل الإصر والأغلال التي كانت على بني إسرائيل. كما

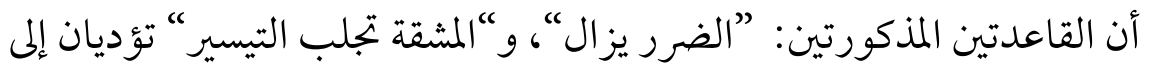
مقصود واحد، وأنها تكادان تتداخلان في المعنى، حتى أنها لتتجاذبان كثيراً من الفروع، وإنها يفرق بينها بأن قاعدة إزالة الضرر تنصب على ضرد واعت واقع

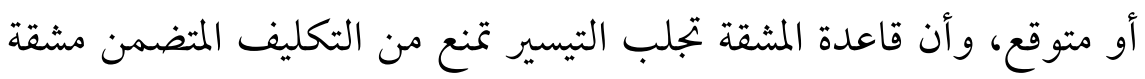
أو المؤدي إليها، مع اعتبار أن المشقة نوع من الضرر وهذا هو معنى التداخل

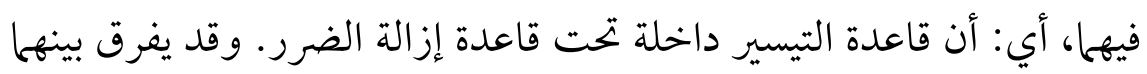
بأن قاعدة التيسير أقرب إلى جلب المصلحة، وقاعدة إزالة الضرر أقرب إلى درء المفسدة، مع وجوب كل من المعنيين في كلا القاعدتين، إلا أن المعنى الإيجابي (جلب المصلحة) أكثر وجوداً في قاعدة التيسير، والمعنى السلبي (درء المفسدة) أكثر مر اعاة في قاعدة إزالة الضرر.

\section{القاعدة الخامسة: العادات محكمة}

العادة في اللغة مأخوذة من العود، وهو الرجوع. يقال: عاد إليه إذ رجع

إليه. والعادة : الديدن يعاد إليه، وجمعها عاد وعادات.(ابن المنظور، 14 14: 16 3). وفي الاصطلاح: ما استمر الناس عليه على حكم المعقول وعادوا إليه

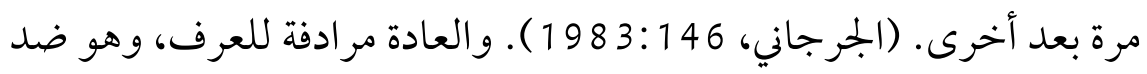
النكر . والعرف و العارفة والمعروف بمعنى واحد. وهو ما تعرفه النفس من الخير

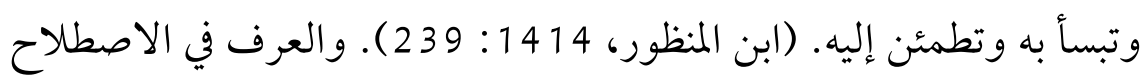
هو ما استقرت النفوس عليه بشهادة العقول وتلقته الطبائع بالقبول.(الجرجاني، 
ومفاد القاعدة أن العادة أو العرف يجعل حكما لإثبات حكم شرعي، وأن

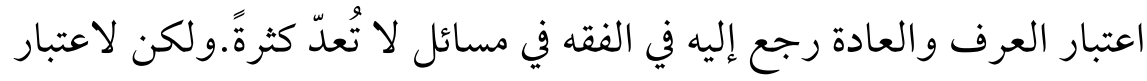

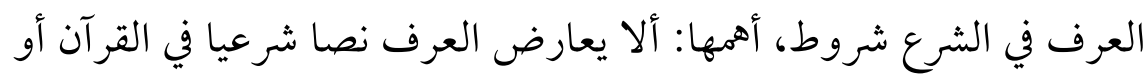

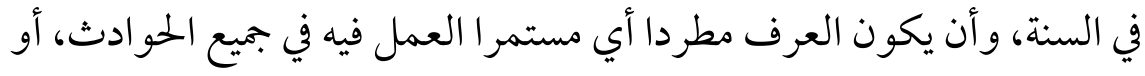
يكون العرف غالبا أي أن يكون العمل به مستمر افي أغلب الو الو قائع.

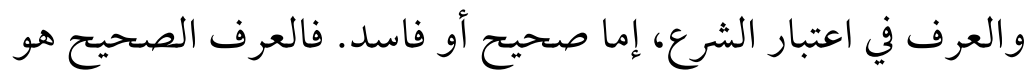

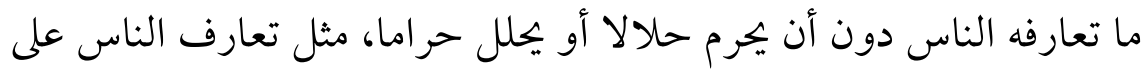

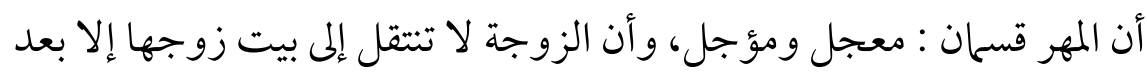
قبض جزء من المهر. وغيرها. والعرف الفاسد هو ما تعارفه الناس ولكنه يحل حراما ويحرم حلالا، مثل تعارف الناس على التعامل بالربا والمقامرة وغيرها.

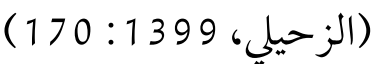

وتستند القاعدة بالأدلة من الكتاب والسنة. ومن الكتاب، قوله

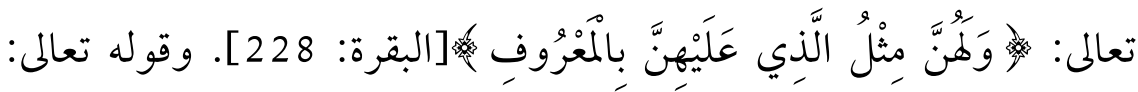

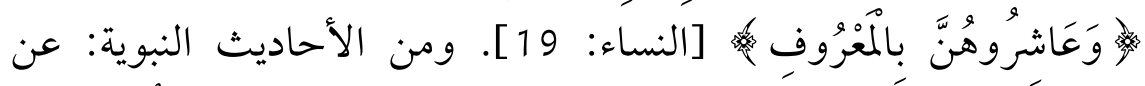

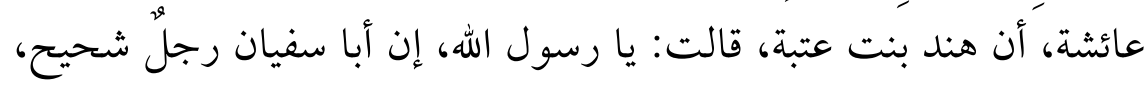

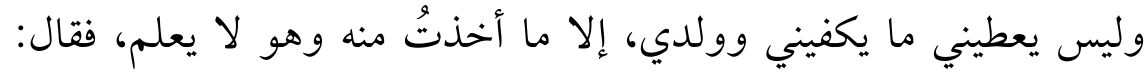

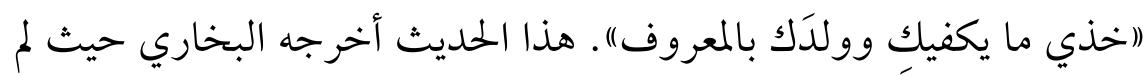

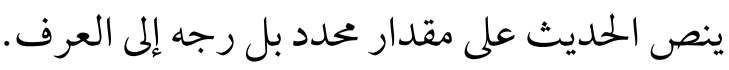

ومن تطبيقات القاعدة في باب الصلاة، هي: الحركة الكثيرة المفسدة

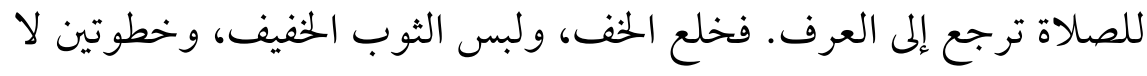

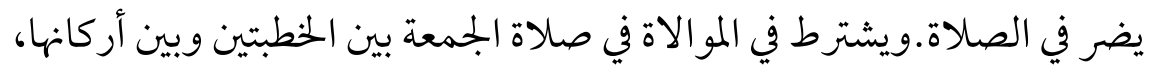

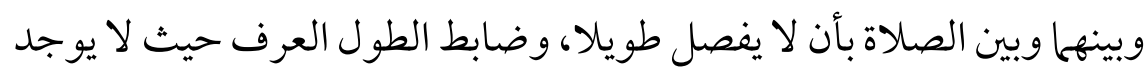
نص في الكتاب أو السنة يجدده. 
أما المثال على تطبيقات هذه القاعدة في باب الزكاة هو سنية اتخاذ الرجل

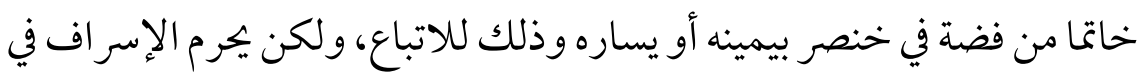

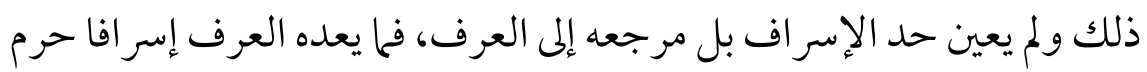

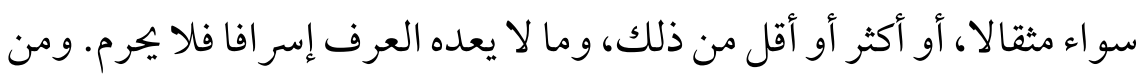

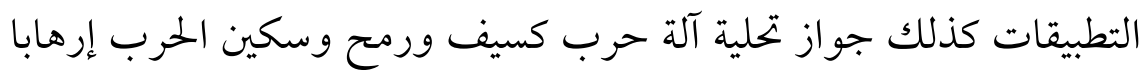

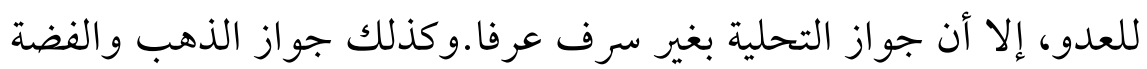

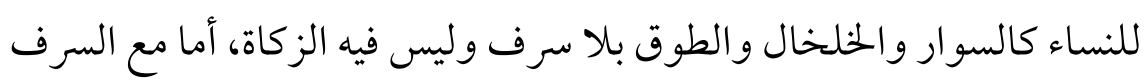
فلا يجوز. ورجع الأذرعي حد السرف إلى العادة وهي العرف الجارئ

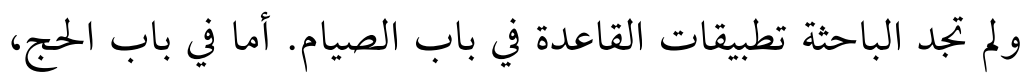

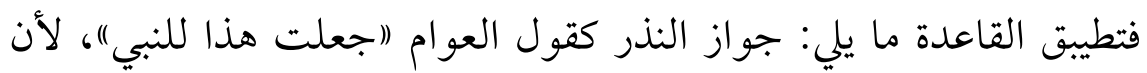

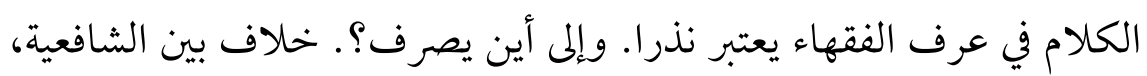
فالسبكي يرى أن النذر يصرف في الكعبة والحجرة الشريفة والمساجد الثرائ الثلاثة.

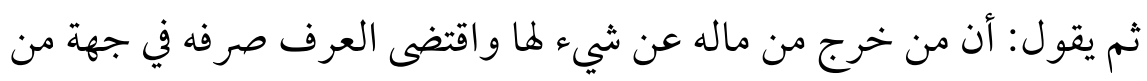
جهاتها: صرف إليها واختصت به.

ت ت الخاتمة

من خلال المباحث السابقة، ترى الباحثة أن السيد البكري من علمهاء

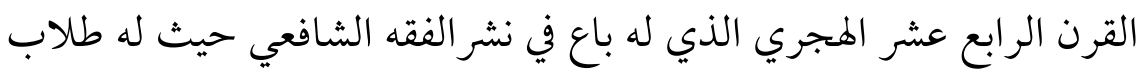

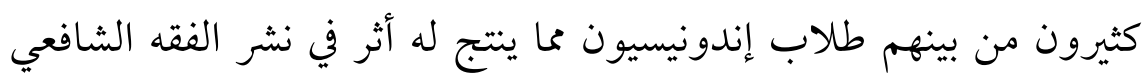

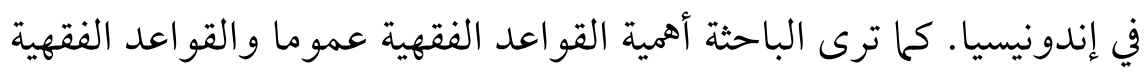

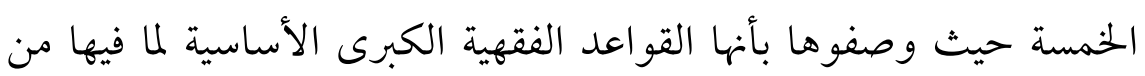

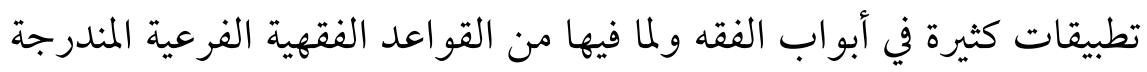

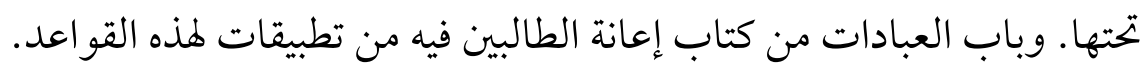
ففي تلك القواعد الخمسة تطبيقاتها في باب العبادات من كتاب إعانة الطالبين 
للسيد البكري. وهذه القو اعد وتطبيقاتها تسهل القارئ في فهم المسألة الفقهية.

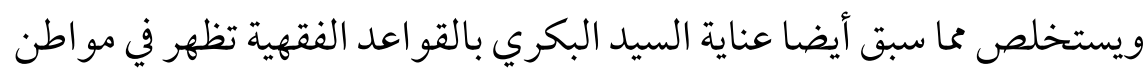
تعليل الأحكام وتخريج المسائل. 


\section{المراجع}

إبر اهيم بن موسى الشاطبي.د.ت.المو افقات.بيروت: دار المعرفة.

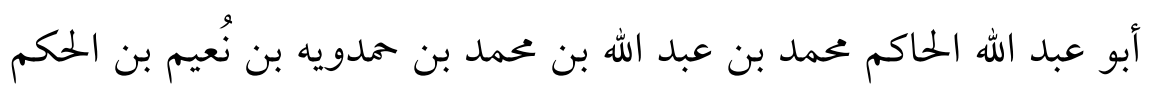
الضبي الطهاني النيسابوري. 1990. المستدرك على على الصحيديدين.

بيروت: دار الكتب العلمية.

أحمد بن حجر العسقلاني. 1410 هـ. فتح الباري. بيروت: دار الكتب بروتبل العلمية.

أكرم يوسف عمر القواسمي. 1423 هـ. المدخل إلى مذهب الإمام الشافعي. الأردن: دار النفائس.

خليل بن كيكلدي العلائي. 1994. المجموع المذهب في قواعد المذهب. الكويت: وزارة الأوقاف والشؤون الإسلامية. خير الدين الزركلي. 1989 ـ الأعلام.بيروت:دار العلم للعالمين. السيد البكري. 100 ـ إعانة الطالبين. بيروت: دار إحياء التراث العربي. شهاب الدين أحمد بن إدريس القرافي.د. ت. الفروق. د.م.: عالم الكتاب. عبد الرحمن بن أبي بكر جلال الدين السيوطي. 1990. الأشباه والنظائر.

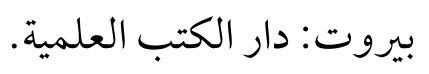

علي بن محمد الجرجاني. 1983 ـ التعريفات. بيروت: دار الكتب العلمية. عمر رضا كحالة. د. ت. معجم المؤلفين. بيروت: دار إحياء التراث العربي. عمر عبد الجبار. 1403 هـ. دروس من ماضيالتعليم وحاضره بالمسجد الحرام. القاهرة: دار مفيس للطباعة. 
مبارك بن محمد ابن الأثير.د.ت. النهاية في غريب الحديث والأثر. عحان: بيت

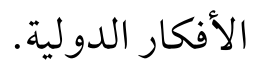

محمد بن أحمد الأزهري. 1000 ـ معجم تهذيب اللغة.بيروت: دار المعرفة. حممد بن بهادر الشافعي الزركشي. 1985، المنثور في القواعد. الكويت: دار النشر مؤسسة الفليج.

حمد صدقي البورنو. 2002 . الوجيز في إيضاح القواعد الفقهية،. بيروت:

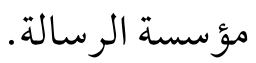

محمد مصطفى شلبي. 1985 ـ المدخل بالتعريف في الفقه الإسالامي.بيروت: دار النهضة العربية.

وهبة الزحيلي. 1399 هـ. نظرية الضرورة الشرعية. بيروت: مؤسسة الرسالة. يميا بن شرف النووي . 2002 ـ المجموع شرح الهذهب. بيروت: دار الكتب العلمية.

د. ت. شرح صحيح مسلم. بيروت: دار الكتب.

العلمية.

يعقوب بن عبد الوهاب الباحسين. 1998. القو اعد الفقهية. الرياض: مكتبة الرشد. 